\title{
Characterization of the Helicase Activity of the Escherichia coli RecBCD Enzyme Using a Novel Helicase Assay ${ }^{\dagger}$
}

\author{
Linda J. Roman and Stephen C. Kowalczykowski* \\ Department of Molecular Biology, Northwestern University Medical School, Chicago, Illinois 60611 \\ Received September 30, 1988; Revised Manuscript Received December 7, 1988
}

\begin{abstract}
We describe an assay to measure the extent of enzymatic unwinding of DNA by a DNA helicase. This assay takes advantage of the quenching of the intrinsic protein fluorescence of Escherichia coli SSB protein upon binding to ssDNA and is used to characterize the DNA unwinding activity of recBCD enzyme. Unwinding in this assay is dependent on the presence of recBCD enzyme and linear dsDNA, is consistent with the known properties of recBCD enzyme, and closely parallels other methods for measuring recBCD enzyme helicase activity. The effects of varying temperature, substrate concentrations, enzyme concentration, and mono- and divalent salt concentrations on the helicase activity of recBCD enzyme were characterized. The apparent $K_{\mathrm{m}}$ values for recBCD enzyme helicase activity on linear M13 dsDNA molecules at $25^{\circ} \mathrm{C}$ are $0.6 \mathrm{nM}$ dsDNA molecules and $130 \mu \mathrm{M}$ ATP, respectively. The apparent turnover number for unwinding is approximately $15 \mu \mathrm{M}$ base pairs s ${ }^{-1}(\mu \mathrm{M} \text { recBCD enzyme })^{-1}$. When this rate is corrected for the observed stoichiometry of recBCD enzyme binding to dsDNA, $k_{\text {cat }}$ for helicase activity corresponds to an unwinding rate of approximately 250 base pairs of DNA s${ }^{-1}$ (functional recBCD complex) ( $^{-1}$ at $25^{\circ} \mathrm{C}$. At $37^{\circ} \mathrm{C}$, the apparent $K_{\mathrm{m}}$ value for dsDNA molecules was the same as that at $25^{\circ} \mathrm{C}$, but the apparent turnover number became $56 \mu \mathrm{M}$ base pairs $\mathrm{s}^{-1}\left(\mu \mathrm{M}\right.$ recBCD enzyme) ${ }^{-1}$ [or 930 base pairs s ${ }^{-1}$ (functional recBCD complex) ${ }^{-1}$ when corrected for observed stoichiometry]. With increasing $\mathrm{NaCl}$ concentration, $k_{\text {cat }}$ peaks at $100 \mathrm{mM}$, and the apparent $K_{\mathrm{m}}$ value for dsDNA increases by 3-fold at $200 \mathrm{mM} \mathrm{NaCl}$. In the presence of $5 \mathrm{mM}$ calcium acetate, the apparent $K_{\mathrm{m}}$ value is increased by 3 -fold, and $k_{\text {cat }}$ decreased by $20-30 \%$. We have also shown that recBCD enzyme molecules are able to catalytically unwind additional dsDNA substrates subsequent to initiation, unwinding, and dissociation from a previous dsDNA molecule.
\end{abstract}

$\mathbf{R}$ enzyme is a $330-\mathrm{kDa}$ protein consisting of three nonidentical subunits with five different activities. It has DNA-dependent ATPase, single-stranded DNA (ssDNA) ${ }^{1}$ and double-stranded DNA (dsDNA) ${ }^{1}$ exonuclease, ssDNA endonuclease, and DNA helicase activities [for reviews, see Telander-Muskavitch and Linn (1981) and Taylor (1988)]. Escherichia coli mutants lacking the recBCD enzyme show a phenotypic reduction in recombination after conjugation or generalized transduction by as much as 3 orders of magnitude and exhibit a reduced ability to recover from DNA damage. Together, recBCD enzyme and recA protein define the RecBCD pathway of recombination, the major pathway used by $E$. coli. RecBCD enzyme has also been shown to nick dsDNA very specifically at $\chi$ sites (Taylor et al., 1985), major recombinational "hotspots" [for a review of $\chi$ sites, see Stahl (1986) or Smith (1987)].

The nuclease activities of recBCD enzyme are inhibited to varying degrees by SSB protein, which binds to ssDNA and protects it from recBCD enzyme nuclease (Mackay \& Linn, 1976), by the presence of calcium ion (Rosamond et al., 1979), and by high levels of ATP. The degradation of dsDNA by recBCD enzyme requires ATP and exhibits an optimum at $20 \mu \mathrm{M}$ ATP, where the final products of the reaction are single-stranded oligonucleotides three to eight bases long (in the absence of SSB protein and calcium ions) (Eichler \& Lehman, 1977; Goldmark \& Linn, 1972). The extent of exonuclease activity is inhibited at high $(>200 \mu \mathrm{M})$ concen-

\footnotetext{
${ }^{\top}$ This work was supported in part by funds from National Institutes of Health Grant AI-18987 and by American Cancer Society Junior Faculty Fellowship JFRA-70.

*Address correspondence to this author.
}

trations of ATP while the initial rate of nuclease activity remains unaffected. The products of the reaction under conditions of high ATP concentration are pieces of ssDNA with lengths ranging from 135 to 1400 nucleotides (Mackay \& Linn, 1976). This difference in products at low and high ATP concentrations led Mackay and Linn (1976) to hypothesize that recBCD enzyme nicks the DNA at a constant rate but moves more quickly through the dsDNA at higher ATP concentration, thus releasing larger product molecules.

While the nuclease activities have been detailed biochemically by several investigators (Eichler \& Lehman, 1977; Mackay \& Linn, 1976; Goldmark \& Linn, 1972), the helicase activity of recBCD enzyme has been studied in vitro only through electron microscopy. Taylor and Smith (1980) and Telander-Muskavitch and Linn (1982) both reported the recBCD enzyme-dependent production of unwound DNA structures such as twin loops, loop tails, and forks as observed via electron microscopy. Both investigators also postulated the following model for the mechanism of formation of these structures. RecBCD enzyme binds to the end of one strand of a linear dsDNA molecule and begins to unwind the duplex. This one strand is assimilated into the recBCD enzyme molecule and subsequently released at a slower rate, thus forming a loop on that strand. In the absence of SSB protein, the strands reanneal behind the recBCD enzyme, forming twin loops. In the presence of SSB protein, reannealing of the complementary strands is prevented, and loop tails or forks

\footnotetext{
${ }^{1}$ Abbreviations: dsDNA, double-stranded DNA; ssDNA, singlestranded DNA; SSB protein, E. coli ssDNA binding protein; RF, replicative form; SDS, sodium dodecyl sulfate; DTT, dithiothreitol; ATP, adenosine triphosphate; EDTA, ethylenediaminetetraacetic acid.
} 
are produced, depending on whether or not recBCD enzyme is still present and holding the loop intact. This model is diagrammed in Figure 6 of the following paper (Roman \& Kowalczykowski, 1989). Thus, the seemingly disparate nuclease, helicase, and ATPase activities of recBCD enzyme can be readily understood in the context of the model proposed for the mechanism of recBCD enzyme function. Since it has been inferred that recBCD enzyme unwinds DNA before or while degrading it (Taylor \& Smith, 1980), recBCD enzyme can be considered an ATP-dependent helicase that functions by entering the end of a dsDNA molecule, unwinding the DNA, and subsequently or concomitantly acting endonucleolytically.

Smith et al. (1984) proposed a model for the involvement of recBCD enzyme in recombination based on the known and relevant activities of the enzyme. A recBCD enzyme molecule enters at a duplex end and unwinds the DNA which rewinds again behind it forming a twin loop. Upon encountering a $\chi$ site, recBCD enzyme nicks the DNA and continues unwinding, thus forming single-stranded portions of DNA which can be used by recA protein to catalyze D-loop formation with a homologous duplex, leading to strand assimilation. The strand from the homologous duplex which has been displaced by recA protein can synapse with the remaining ssDNA from the original molecule unwound by recBCD enzyme, thus forming a classic Holliday junction. These molecules are then resolved, and recombination has occurred. This model assumes that recBCD enzyme acts at an early stage in recombination by creating a substrate for recA protein and there is some in vivo support for early action of recBCD enzyme (Yancey \& Porter, 1985; Porter et al., 1978). There is also genetic evidence that recBCD enzyme acts later in recombination (Birge \& Low, 1974).

Detailed biochemical studies of the helicase activity of recBCD enzyme have not yet been performed. Such studies are crucial to the understanding and integration of all the various activities of the enzyme and their involvement in recombination. They are also necessary for the purpose of duplicating such a system in vitro. To examine the biochemistry of recBCD enzyme, we have developed a continuous helicase assay which will measure the total amount of unwinding whether the product molecules are completely or only partially unwound. Our method takes advantage of the intrinsic protein fluorescence of SSB protein which is quenched upon binding to ssDNA. RecBCD enzyme unwinds the dsDNA, producing ssDNA which is accessible to SSB protein. The SSB protein then binds immediately to this SsDNA, resulting in a decrease in the intrinsic protein fluorescence of the SSB protein. This fluorescence decrease is easily monitored and accurately reflects recBCD enzyme helicase activity when compared with the results obtained in other assays.

\section{Materials ANd Methods}

Protein and DNA Isolation. Both ss- and dsDNA M13 mp7 molecules were isolated according to the procedures of Messing (1983). The molar concentrations of nucleotides were determined by using extinction coefficients of $6500 \mathrm{M}^{-1} \mathrm{~cm}^{-1}$ for dsDNA and $8780 \mathrm{M}^{-1} \mathrm{~cm}^{-1}$ for ssDNA at $260 \mathrm{~nm}$. This was converted to molar concentration of dsDNA molecules by dividing the molar concentration of nucleotides by 14390 nucleotides per duplex molecule. The dsDNA was linearized by digestion with EcoRI.

SSB protein was purified from strain RLM727 (which contains the cloned SSB gene on plasmid RLM55 under the control of $\lambda \mathrm{cI857)}$ by using a preparative protocol provided by Dr. Roger McMacken of The Johns Hopkins University.
The protein concentration was determined by using a molar extinction coefficient of $3 \times 10^{4} \mathrm{M}^{-1} \mathrm{~cm}^{-1}$ at $280 \mathrm{~nm}$.

RecBCD enzyme was purified from $E$. coli strain V320 (strain $\mathrm{AC1} 13$ with a deletion of the chromosomal recB, recC, and recD genes, and containing pDWS103, which is pMOB45 containing these genes). This strain was provided by Dennis Schultz and Gerald Smith at the Fred Hutchinson Cancer Research Center. RecBCD enzyme was purified by using a procedure based on those of Dykstra et al. (1984) and Eichler and Lehman (1977). The units used to determine the specific activity of the enzyme were based on nuclease activity as defined by Eichler and Lehman (1977) using ${ }^{3} \mathrm{H}$-labeled $E$. coli chromosomal DNA which had been sonicated for $15 \mathrm{~min}$ in a Fisher Model 30 sonic dismembrator using the microtip at $35 \%$ of maximum. The amount of enzyme used in these nuclease assays was less than 1 unit as we have found this assay to be nonlinear with larger amounts of enzyme. All of the following manipulations were performed at $4^{\circ} \mathrm{C}$, unless otherwise indicated.

The two preparations of recBCD enzyme used in this paper were produced with minor differences in procedure. Both preparations produced enzyme which appeared greater than $95 \%$ pure on a Coomassie-stained polyacrylamide gel, and the second is described in detail below. The differences in the first preparation are noted at the end of the procedure.

Ten liters of $L$ broth was inoculated with a $500-\mathrm{mL}$ overnight culture containing $30 \mu \mathrm{g} / \mathrm{mL}$ chloramphenicol and grown at $30^{\circ} \mathrm{C}$. The ten liters of cells was then grown at $30^{\circ} \mathrm{C}$ in the presence of $30 \mu \mathrm{g} / \mathrm{mL}$ chloramphenicol until the absorbance at $595 \mathrm{~nm}$ was between 0.6 and 0.8 optical density unit. The temperature was shifted to $42^{\circ} \mathrm{C}$, and cells were grown until stationary phase was reached and then harvested.

The cells $(40 \mathrm{~g})$ were lysed according to the procedure of Weinstock et al. (1979). The lysate was then fractionated with $0.282 \mathrm{~g} / \mathrm{mL}$ ammonium sulfate and spun at $25900 \mathrm{~g}$ for $90 \mathrm{~min}$ to recover the precipitated protein. The pellet was resuspended in and dialyzed against buffer $\mathrm{B}(20 \mathrm{mM}$ Tris- $\mathrm{HCl}, \mathrm{pH} 7.5$, $0.1 \mathrm{mM}$ EDTA, $0.1 \mathrm{mM}$ dithiothreitol, and $100 \mathrm{mM} \mathrm{NaCl}$ ).

The dialyzate was applied to a $100-\mathrm{mL} \mathrm{Q}-$ Sepharose column (Pharmacia) equilibrated with buffer $\mathrm{B}$ and eluted with a $500-\mathrm{mL}$ continuous salt gradient of $100-600 \mathrm{mM} \mathrm{NaCl}$. RecBCD enzyme activity elutes at approximately $450 \mathrm{mM}$ $\mathrm{NaCl}$. The active fractions were pooled and dialyzed immediately against buffer $\mathrm{C}(50 \mathrm{mM}$ sodium phosphate, $\mathrm{pH} 7.0$, and $1 \mathrm{mM}$ dithiothreitol), as the activity tends to be rather labile if left in high salt, possibly due to the dissociation of the recD protein subunit.

The dialyzate was then applied to a $10-\mathrm{mL}$ hydroxylapatite column (Bio-Rad Biogel HTP) equilibrated in buffer $\mathrm{C}$ and eluted with a $100-\mathrm{mL}$ continuous salt gradient of $50-400 \mathrm{mM}$ sodium phosphate, pH 7.0. RecBCD enzyme activity elutes at approximately $200 \mathrm{mM}$ sodium phosphate. The active fractions were pooled and dialyzed against buffer $B$.

The dialyzate was then applied to a $45-\mathrm{mL}$ ssDNA-cellulose column [prepared with heat-denatured calf thymus DNA using the method of Litman (1968)], washed with buffer B, and eluted with buffer $B$ containing $700 \mathrm{mM} \mathrm{NaCl}$. The active fractions were pooled and either were dialyzed against buffer $B$ to remove the salt and concentrated or were concentrated and applied immediately to a $25-\mathrm{mL}$ Superose 12 gel filtration column (Pharmacia). RecBCD enzyme activity elutes in a distinct peak near the void volume, corresponding to a molecular weight of approximately $300 \mathrm{~K}$. The active fractions were pooled and dialyzed against buffer B with $50 \%$ glycerol and stored at $-80^{\circ} \mathrm{C}$. 
The first preparation of recBCD enzyme was identical with that described above except that the Superose 12 gel filtration column was omitted. Instead, a S-400 gel filtration column (Pharmacia), equilibrated in buffer $B$, was run just after the Q-Sepharose column but before the hydroxylapatite column.

All experiments described in this paper were done with preparations of recBCD enzyme which appear to be greater than $95 \%$ pure with a $\operatorname{recB}$, recC, and recD subunit stoichiometry of $1: 1: 1$ within about $10 \%$ error when $2 \mu \mathrm{g}$ of protein is loaded on a Coomassie-stained SDS-polyacrylamide gel. When the same gel is silver stained, two additional polypeptide bands appear at 84 and $60 \mathrm{kDa}$. The majority of experiments were done with the second preparation, but both preparations yielded the same experimental results. Identical results were also obtained with a preparation provided by Andrew Taylor of the Fred Hutchinson Cancer Center [fraction IV of Taylor and Smith (1985)] and with a later preparation of recBCD enzyme which had a higher specific activity than the preparations used for this paper, when equal nuclease units of each enzyme were used.

RecBCD enzyme concentration was determined by using a molar extinction coefficient of $4.0 \times 10^{5} \mathrm{M}^{-1} \mathrm{~cm}^{-1}$ at 280 $\mathrm{nm}$. This molar extinction coefficient is based on its calculated absorbance based on the aromatic amino acid composition and a molecular weight of 329806 for recBCD enzyme, as determined from its nucleic acid sequence (Finch et al., 1986a-c). The calculated $\mathrm{OD}_{280} / \mathrm{OD}_{260}$ is 1.49 ; the value obtained for our preparations of recBCD enzyme varied from 1.2 to 1.6. The enzyme concentration was also determined by using the Coomassie stain based Bio-Rad protein assay with BSA as a standard. The concentration determined by the Bio-Rad method was only $50 \%$ of that calculated by using the optical density at $280 \mathrm{~nm}$. The recBCD enzyme concentrations reported in this paper are those derived from the optical density at $280 \mathrm{~nm}$.

The final enzyme had a specific activity of $3.4 \times 10^{4} \mathrm{nu}$ clease units $/ \mathrm{mg}$, only $11 \%$ of the value of fraction $\mathrm{V}$ of Amundsen et al. (1986), who report the highest specific activity achieved to date ( $3 \times 10^{5}$ units $/ \mathrm{mg}$ ). Our value is similar to that of fraction IV of Amundsen et al. (1986) and those of Ponticelli et al. (1985) and Taylor and Smith (1985). Assuming a molecular weight of $330 \mathrm{~K}$ for recBCD enzyme, our preparation was calculated to have $5.4 \times 10^{10}$ enzyme molecules/unit of nuclease activity or $1.12 \times 10^{4}$ units $/ \mathrm{nmol}$ of enzyme.

Reaction Conditions. The reaction mixture for the helicase assays consisted of $25 \mathrm{mM}$ Tris-acetate ( $\mathrm{pH} 7.5$ ), $1 \mathrm{mM}$ magnesium acetate, $1 \mathrm{mM}$ dithiothreitol, $1 \mathrm{mM} \mathrm{ATP}$, and an ATP-regenerating system consisting of $2 \mathrm{mM}$ phosphoenolpyruvate and 16 units of pyruvate kinase $/ \mathrm{mL}$, unless otherwise indicated. The assays were performed in either a $1.5-\mathrm{mL}$ or a $250-\mu \mathrm{L}$ total volume with no difference observed between the two. The amount of SSB protein in any given reaction is $20 \%$ of the dsDNA concentration in nucleotides, unless otherwise indicated. Molineux et al. (1975) have shown that the intrinsic protein fluorescence of SSB protein is quenched about $66 \%$ in the presence of saturating amounts of ssDNA; the amount of quenching observed in our reactions is only $30 \%$ since we use $1.5 \times$ saturating amounts of SSB protein, based on a site size of 15 nucleotides per monomer. Bujalowski and Lohman (1986) have thoroughly investigated both the binding stoichiometry and the quenching of SSB protein under various sodium and magnesium ion concentrations and show that, for the conditions described in this paper, the binding stoichiometry and quenching of SSB protein intrinsic fluorescence change very little. Several control experiments performed at the various salt concentrations described in this paper confirm that the amount of fluorescence quenching remains constant.

The amounts of dsDNA and recBCD enzyme in the reactions are specified in the figure legends. The reactions were initiated by the addition of either the recBCD enzyme or the dsDNA; no difference is observed between the enzyme-initiated and the DNA-initiated reactions. Reaction temperatures were thermoregulated to $25^{\circ} \mathrm{C}$, unless otherwise indicated, and the reaction mixture was stirred constantly. All rates are reported in the units micromolar base pairs unwound per second per micromolar recBCD enzyme.

Fluorometric Helicase Assay. The helicase activity of recBCD enzyme is monitored by observing the quenching of the intrinsic protein fluorescence of SSB protein upon binding to ssDNA. The decrease in fluorescence was monitored, and data were collected by using a Perkin-Elmer MPE-44E fluorescence spectrophotometer interfaced to a Hewlett Packard 85 microcomputer. The excitation and emission wavelengths were set at 290 and $340 \mathrm{~nm}$, respectively, and both the excitation and emission slit widths were set to $5 \mathrm{~nm}$.

Agarose Gel Helicase Assay. The disappearance of dsDNA molecules during a helicase assay can be monitored by electrophoresing aliquots of the reaction in an agarose gel. Samples $(40 \mu \mathrm{L})$ of the above reaction mixture containing 0.69 $n M$ linear dsDNA molecules, 0 or $2 \mu \mathrm{M}$ SSB protein, and 8.5 $\mathrm{nM}$ recBCD enzyme were added to $5 \mathrm{mM}$ EDTA and $1 \%$ SDS at indicated time points to halt the reaction. These samples were loaded onto a $0.8 \%$ agarose gel and electrophoresed in TAE buffer ( $40 \mathrm{mM}$ Tris-acetate and $2 \mathrm{mM}$ EDTA). The disappearance of duplex was quantitated by scanning a photographic negative of the gel with a Zeineh soft laser scanning densitometer (Biomed Instruments, Inc.) interfaced to a Hewlett Packard 3390A integrator.

S1 Nuclease Assay. Aliquots $(50 \mu \mathrm{L})$ of the above reaction mixture, but using tritium-labeled dsDNA, were stopped at various times with 0.1 volume of SDS and put on ice. S1 nuclease digest buffer $(300 \mu \mathrm{L})(60 \mathrm{mM}$ sodium acetate, 100 $\mathrm{mM}$ sodium chloride, and $2 \mathrm{mM}$ zinc chloride, $\mathrm{pH} 4.6$ ) was added to each aliquot along with approximately 40 units of S1 nuclease. After incubation at $37^{\circ} \mathrm{C}$ for $30 \mathrm{~min}$, calf thymus DNA ( $15 \mu \mathrm{L}$ of a $2.5 \mathrm{mg} / \mathrm{mL}$ stock) and $15 \%$ trichloroacetic acid $(300 \mu \mathrm{L})$ were added. The sample was put on ice for 15-30 min and then spun down in a microfuge for $10 \mathrm{~min}$. The supernatant $(500 \mu \mathrm{L})$ was removed, added to approximately $7 \mathrm{~mL}$ of scintillation cocktail, and counted for 1 or $5 \mathrm{~min}$ in a Beckman scintillation counter. These data are normalized by the total number of counts in an aliquot.

\section{RESULTS}

A Fluorometric Assay That Measures the Unwinding of dsDNA by RecBCD Enzyme Helicase Activity. A novel assay for the helicase activity of recBCD enzyme can be used to generate a continuous time course of the unwinding of dsDNA. The assay takes advantage of the quenching of $E$. coli SSB protein intrinsic fluorescence upon binding to the ssDNA produced by the action of recBCD enzyme (Figure 1A). The raw data consist of a time-dependent decrease in the intrinsic protein fluorescence. Typical data are shown in Figure 1B for several different concentrations of recBCD enzyme. Classic enzymatic behavior is observed in that increasing the enzyme concentration results in an increase in the initial rate. All reactions shown eventually reach the final extent as shown by line E (3.35 nM recBCD enzyme) in Figure 1B. No decrease in fluorescence occurs in the absence of either recBCD enzyme (line O) or dsDNA (data not shown). 
Table I: Initial Rates and Final Extents of Unwinding of dsDNA by RecBCD Enzyme ${ }^{a}$

\begin{tabular}{|c|c|c|c|}
\hline row & variable & $\begin{array}{c}\text { initial rate } \\
{\left[\mu \mathrm{M} \mathrm{bp} \mathrm{s}^{-1}\right.} \\
(\mu \mathrm{M} \\
\left.\mathrm{recBCD})^{-1}\right]\end{array}$ & $\begin{array}{l}\text { extent }(\% \\
\text { of total) }\end{array}$ \\
\hline & [SSB protein] $(\mu \mathrm{M})$ & & \\
\hline 1 & 0.2 & 3.5 & 55 \\
\hline 2 & 0.4 & 3.7 & 71 \\
\hline 3 & 0.6 & 3.7 & 79 \\
\hline 4 & 0.8 & 3.8 & 76 \\
\hline 5 & $\begin{array}{c}1.0 \\
\text { [gene } 32 \text { protein] }(u \mathrm{M})\end{array}$ & 3.6 & 78 \\
\hline 6 & 0.6 & 2.2 & 52 \\
\hline 7 & $\stackrel{1.2}{[\mathrm{ss} D N A] \operatorname{prior}^{b}(\mathrm{nM})}$ & 3.6 & 80 \\
\hline 8 & $\begin{array}{l}0.14 \\
{[\mathrm{ssDNA}] \operatorname{after}^{c}(\mathrm{nM})}\end{array}$ & 3.7 & 75 \\
\hline 9 & 0.14 & 3.4 & 74 \\
\hline
\end{tabular}

${ }^{\circ}$ All reactions contained $0.14 \mathrm{nM}$ linear M13 DNA molecules and $2.4 \mathrm{nM}$ recBCD enzyme. Reactions were begun with the addition of dsDNA, and all rates are reported in units of micromolar base pairs unwound per second per micromolar recBCD enzyme. ${ }^{b} \mathrm{M} 13 \mathrm{mp} 7$ single-stranded DNA (0.14 nM molecule) was added prior to the start of the reaction. Reaction contained $0.4 \mu \mathrm{M}$ SSB protein. ${ }^{C} \mathrm{M} 13 \mathrm{mp} 7$ single-stranded DNA (0.14 $\mathrm{nM}$ molecule) was added after the start of the reaction. Reaction contained $0.4 \mu \mathrm{M}$ SSB protein

The percent of DNA unwound is calculated from the raw fluorescence data by dividing the observed fluorescence change by the total fluorescence quenching of SSB protein obtained in the presence of an equivalent concentration of heat-denatured, rather than intact, dsDNA. This total fluorescence quenching is assumed to be equivalent to $100 \%$ unwinding of the DNA and was determined under all of the various buffer conditions (i.e., varying ATP and mono- and divalent salt concentrations) to control for possible changes in the amount of total fluorescence quenching with changing conditions. A time course normalized in this manner is shown for $8.5 \mathrm{nM}$ recBCD enzyme in Figure 2, solid line. The initial rate of unwinding is calculated from this normalized data by drawing a line tangent to the beginning of the time course. The slope of this tangent is equal to the initial rate. The percent of DNA unwound at the final plateau of the reaction is designated the final extent of unwinding. Assays performed under the conditions shown in Figure 2 typically have an initial rate of 9 $\pm 2 \mu \mathrm{M}$ base pairs $\mathrm{s}^{-1}$ ( $\mu \mathrm{M}$ recBCD enzyme $)^{-1}$ and a final extent of unwinding ranging from 75 to $100 \% .^{2}$

To ensure that the rate-limiting step of this reaction is dependent only on the helicase activity of recBCD enzyme and is not limited by the association rate of SSB protein to the ssDNA produced, SSB protein concentration was varied. No difference in initial rate or extent of unwinding is observed at SSB protein concentrations greater than or equal to 1.5-fold the amount needed to saturate both strands of the dsDNA (Table I, rows 1-5). All subsequent reactions discussed in this paper contained at least enough SSB protein to saturate 1.5fold all the ssDNA produced if the reaction had proceeded to $100 \%$ unwinding. The SSB protein concentration was also varied at higher dsDNA concentrations (i.e.,1.74 nM) to en-

2 The extent of unwinding was, at minimum, $75 \%$ and as high as $100 \%$, but was more typically about $85 \%$. This variation in the extent unwound was dependent on the DNA preparation used and appeared to correlate with the amount of nicked circular dsDNA present in the preparation of RF DNA prior to the EcoRI digest. The initial rates of unwinding, however, were identical with all DNA preparations; only the extents of unwinding were altered. This suggests that modifications in the dsDNA may impede the helicase activity of recBCD enzyme; this observation has not been rigorously verified.

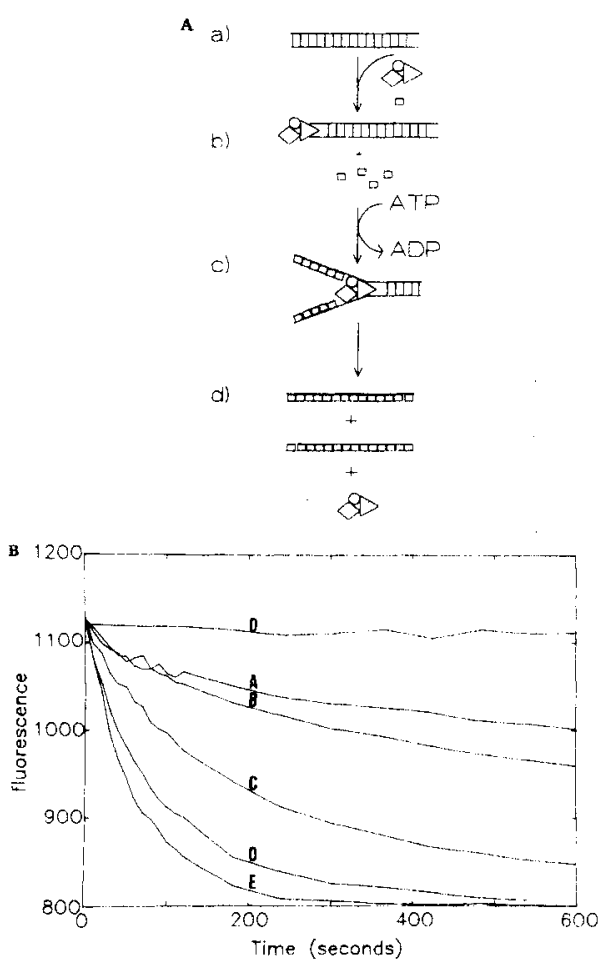

FIGURE 1: Fluorometric detection of recBCD enzyme helicase activity. The recB, recC, and recD subunits are represented by the triangles, diamonds, and circles, respectively. (A) Diagram of the helicase assay used. RecBCD enzyme binds to the end of a dsDNA molecule (b) and, accompanied by the hydrolysis of ATP, begins to unwind the duplex molecule. The ssDNA produced is immediately bound by SSB protein (rectangles) (c), resulting in a decrease of the intrinsic protein fluorescence of SSB protein. The reaction continues until the final product, DNA molecules which are completely single stranded, is produced (d). This diagram oversimplifies the types of DNA molecules produced by recBCD enzyme. "Loop-tails" and forked molecules are both observed in the electron microscope (Taylor \& Smith, 1980; Telander-Muskavitch \& Linn, 1980). In principle, any catalytically acting helicase which is unaffected by SSB protein could substitute for recBCD enzyme in this assay. (B) Profile of the fluorescence decrease as a function of recBCD enzyme concentration: lines $A-F$ are $0.17,0.34,0.84,1.68$, and $3.36 \mathrm{nM}$, respectively. Line 0 is $0 \mathrm{nM}$ recBCD enzyme. Assays contained $0.14 \mathrm{nM}$ linear DNA and 0.4 $\mu \mathrm{M}$ SSB protein. Standard reaction conditions were used. Fluorescence units are arbitrary.

sure that SSB protein was not limiting in reactions proceeding at higher rates, and no effect was observed (data not shown). The substitution of T4 gene 32 protein for SSB protein does not alter the reaction profile, further supporting the role of SSB protein as a reporter molecule in this reaction (Table I, rows 6 and 7). RecBCD enzyme does have an intrinsic fluorescence of its own, but it does not change over the course of the reaction (data not shown).

To confirm that this assay is indeed measuring the unwinding of the dsDNA by recBCD enzyme, a variety of experiments were performed. Supercoiled M13 RF duplex does not support this activity whether the recBCD concentration is $1.68 \mathrm{nM}$ (Figure 2) or $25.3 \mathrm{nM}$ (data not shown). This is consistent with the fact that recBCD enzyme requires a duplex end to initiate unwinding (Taylor \& Smith, 1985) or degradation (Goldmark \& Linn, 1972).

The helicase activity of recBCD enzyme has been shown to have an absolute requirement for magnesium ions (Taylor \& Smith, 1980; Telander-Muskavitch \& Linn, 1981). When $5 \mathrm{mM}$ EDTA is added to an ongoing helicase assay in our system to chelate the $1 \mathrm{mM}$ magnesium ions present, activity stops immediately (Figure 2, dashed line). Activity is resumed with the subsequent addition of $10 \mathrm{mM}$ magnesium acetate, 


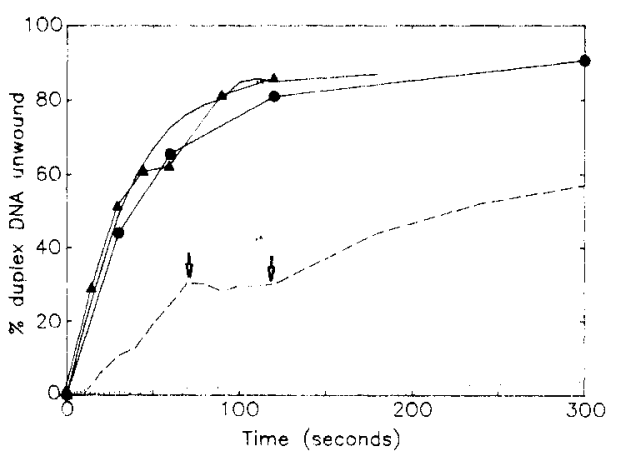

FIGURE 2: Comparison of recBCD enzyme helicase activity using different assays. Fluorometric helicase assay with linear dsDNA (solid line); agarose gel assay with linear dsDNA (circles); S1 nuclease assay with linear dsDNA (triangles); fluorometric assay with supercoiled RF M13 DNA (dotted line); fluorometric assay with $5 \mathrm{mM}$ EDTA added at first arrow and $10 \mathrm{mM} \mathrm{MgCl} 2$ added at second arrow (dashed line). Fluorometric assay with EDTA contained $0.14 \mathrm{nM}$ linear dsDNA, $0.4 \mu \mathrm{M}$ SSB protein, and $1.68 \mathrm{nM}$ recBCD enzyme; other fluorometric assays, $\mathrm{S} 1$ nuclease assay, and agarose gel assay contained $0.69 \mathrm{nM}$ dsDNA molecules, $2 \mu \mathrm{M}$ SSB protein, and $8.5 \mathrm{nM}$ recBCD enzyme. Standard fluorometric, agarose gel, and $\mathrm{S} 1$ nuclease reaction conditions were used.

indicating that the helicase activity we are measuring also displays an absolute magnesium requirement. The final extent of the reaction is the same as that of a normal, uninterrupted assay under these conditions. This implies that recBCD enzyme molecules did not dissociate from the DNA in the $a b$ sence of magnesium ion since they would be unable to reinitiate unwinding on substrates with long ssDNA tails (Taylor \& Smith, 1985).

To ascertain whether all of the dsDNA molecules were fully unwound at the end of a reaction, additional recBCD enzyme was added at the plateau. Since it is possible that recBCD enzyme is unable to initiate on the product DNA structures present, this experiment actually measures whether any of the remaining DNA molecules can be further unwound by additional recBCD enzyme. This additional recBCD enzyme does not produce a further change, indicating that the dsDNA is fully unwound with regard to recBCD enzyme activity (data not shown).

To determine whether recBCD enzyme binds preferentially to duplex or ssDNA molecules in the presence of SSB protein (which will compete with recBCD enzyme for the ssDNA), ssDNA $(0.14 \mathrm{nM})$ was added to an ongoing reaction containing dsDNA $(0.14 \mathrm{nM})$ and SSB protein $(0.8 \mu \mathrm{M})$. After an immediate decrease in fluorescence due to the instantaneous binding of SSB protein to the added ssDNA, the reaction continued as if the ssDNA was not present. The same result was obtained when the ssDNA was present before the addition of the dsDNA; that is, the reaction continues as if the ssDNA was not present (Table I, rows 8 and 9).

Figure 2 also shows a comparison between time courses of the fluorometric, agarose gel, and S1 nuclease assays for helicase activity. In the agarose gel assay, the rate of the disappearance of the dsDNA is measured. The appearance of intact ssDNA molecules is not observed in the absence of calcium ion due to the presence of recBCD enzyme dsDNA nuclease activity although, under these conditions, no trichloroacetic acid soluble DNA fragments are produced. Since, however, Taylor and Smith (1980) have inferred that recBCD enzyme unwinds the DNA before or while degrading it, unwinding can be calculated by quantifying the disappearance of the dsDNA. In the $\mathrm{S} 1$ nuclease assay, recBCD enzyme unwinding activity produces ssDNA which is sensitive to $S 1$ nuclease; the production of acid-soluble tritium label is mea-

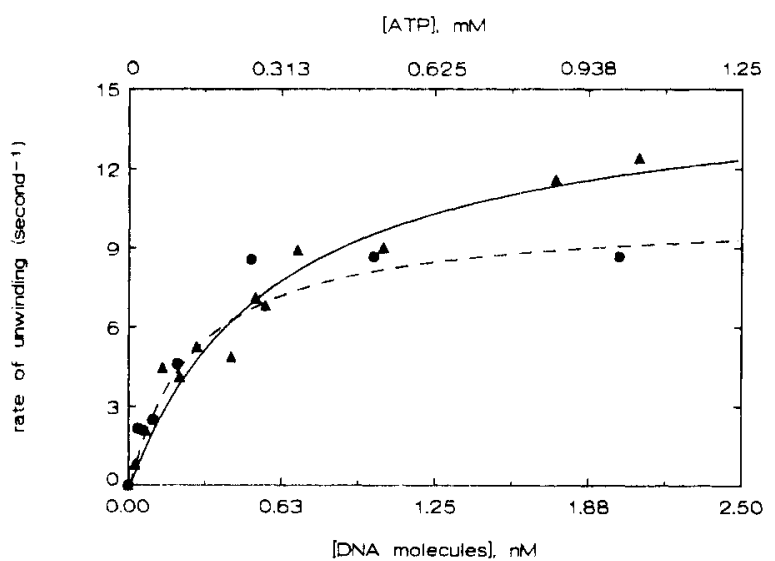

FIGURE 3: Effect of varying substrate concentrations on recBCD enzyme helicase activity: DNA (triangles, solid line); ATP (circles, dashed line). The reactions involving varying DNA concentration contained 1.5-fold the amount of SSB protein necessary to saturate the amount of DNA present, $1 \mathrm{mM}$ ATP, and $2.4 \mathrm{nM}$ recBCD enzyme. The reactions involving varying ATP concentration contained $0.69 \mathrm{nM}$ dsDNA, $2 \mu \mathrm{M}$ SSB protein, and $2.4 \mathrm{nM}$ recBCD enzyme: Data were fit to a hyperbola to yield the apparent $k_{\text {cat }}$ and the $K_{\mathrm{m}}$ value for the DNA substrate. Initial rates are plotted, and all rates are reported in units of micromolar base pairs unwound per second per micromolar recBCD enzyme.

sured. Figure 2 demonstrates that the time course of unwinding is identical in all three assays. The rate of dsDNA disappearance in the agarose gel assay was also identical when SSB protein was not present (not shown), indicating that SSB protein does not alter the rate of recBCD enzyme unwinding activity. All of the above data support the interpretation that this fluorometric assay measures exclusively the unwinding of the dsDNA molecule by recBCD enzyme.

Effect of Temperature on RecBCD Enzyme Helicase ACtivity. Temperature was varied from 16 to $37^{\circ} \mathrm{C}$ to determine the temperature where the reaction is slow enough to be readily assayed. Using the conditions described in Table I with 0.4 $\mu \mathrm{M}$ SSB protein, the initial rates of unwinding at $16,25,30$, and $37^{\circ} \mathrm{C}$ were $1.6,3.6,5.6$, and $7.4 \mathrm{~s}^{-1}$, respectively (data not shown). At $25^{\circ} \mathrm{C}$, a reaction mixture, containing 0.14 $\mathrm{nM}$ dsDNA molecules and $2.4 \mathrm{nM}$ recBCD enzyme, is completed in approximately $1.5-2 \mathrm{~min}$. At $37^{\circ} \mathrm{C}$, the same reaction is completed in less than $1 \mathrm{~min}$, making data analysis less accurate. Since the rate of unwinding is faster at higher recBCD enzyme or DNA concentrations, $25^{\circ} \mathrm{C}$ was chosen as the "standard" temperature for most assays because the rate of the reaction is slow enough to obtain accurate and reproducible data over a wide range of experimental conditions.

Since these rates of unwinding were obtained by using a dsDNA concentration that is below the apparent $K_{\mathrm{m}}$ value of recBCD enzyme helicase for dsDNA, the rates reported are not maximal rates. However, an Arrhenius plot of the rate data will yield an apparent energy of activation $\left(E_{\mathrm{a}}\right)$ for helicase activity. This apparent $E_{\mathrm{a}}$ value is equal to $9.7 \mathrm{kcal}$.

Effect of Substrate Concentrations on RecBCD Helicase Activity. The concentrations of the two substrates of the recBCD helicase activity, ATP and dsDNA, were varied to establish apparent $K_{\mathrm{m}}$ values and the apparent turnover number $\left(k_{\text {cat }}\right.$ value). The initial reaction rates obtained from experiments in which DNA concentration was varied are shown in Figure 3 (triangles). The concentration of dsDNA is presented in the units of nanomolar DNA molecules because it is more appropriate to assume that a dsDNA molecule, rather than a nucleotide, is the actual substrate, since recBCD enzyme enters only at an end of a dsDNA molecule (Taylor \& Smith, 1985). 
Table II: Kinetic Parameters for dsDNA of the Helicase Activity of RecBCD Enzyme ${ }^{a}$

\begin{tabular}{ccccc}
\hline row & variable & app $K_{\mathrm{m}}(\mathrm{nM})$ & $\begin{array}{c}\text { app } k_{\text {cat }} \\
\left(\mathrm{s}^{-1}\right)\end{array}$ & $\operatorname{cor}^{c} k_{\text {cat }}\left(\mathrm{s}^{-1}\right)$ \\
\hline & {$[\mathrm{NaCl}](\mathrm{mM})$} & & & \\
1 & 0 & $0.6 \pm 0.1$ & $15 \pm 1.2$ & $250 \pm 20$ \\
2 & 50 & $0.7 \pm 0.4$ & $21 \pm 4.7$ & $340 \pm 78$ \\
3 & 100 & $1.5 \pm 0.4$ & $29 \pm 4.9$ & $470 \pm 81$ \\
4 & 150 & $2.1 \pm 0.2$ & $25 \pm 1.4$ & $410 \pm 23$ \\
5 & 200 & $1.8 \pm 0.1$ & $17 \pm 0.6$ & $290 \pm 10$ \\
& {$[\mathrm{CaOAc}](\mathrm{mM})$} & & & \\
6 & 1 & $0.7 \pm 0.2$ & $11 \pm 1.2$ & $180 \pm 20$ \\
7 & 5 & $2.3 \pm 0.1$ & $12 \pm 3.7$ & $210 \pm 61$ \\
8 & $1^{b}$ & $0.6 \pm 0.2$ & $12 \pm 1.3$ & $200 \pm 21$ \\
9 & temp $\left.{ }^{\circ} \mathrm{C}\right)$ & & & \\
9 & 37 & $1.1 \pm 0.3$ & $56 \pm 0.9$ & $930 \pm 15$ \\
\hline
\end{tabular}

${ }^{a}$ All reactions contained $2.4 \mathrm{nM}$ recBCD enzyme. The reactions described by rows $1-7$ were performed at $25^{\circ} \mathrm{C}$. The amount of SSB protein in the reactions at $25^{\circ} \mathrm{C}$ was equal to $20 \%$ of the amount of dsDNA nucleotides used. The amount of SSB protein in the reactions at $37^{\circ} \mathrm{C}$ was equal to $40 \%$ of the amount of dsDNA nucleotides present. ${ }^{b}$ This reaction was performed at $37^{\circ} \mathrm{C}$ and in the presence of 5 mM ATP. "The "corrected $k_{\text {cat }}$ " is the "apparent $k_{\text {cat }}$ " multiplied by the observed stoichiometry of recBCD enzyme binding to dsDNA. For the recBCD enzyme preparation used in this table, the experimentally observed stoichiometry was $16.5 \mathrm{recBCD}$ enzyme molecules per dsDNA molecule end.

When the DNA substrate concentration data are fitted to a hyperbola, an apparent turnover number $\left(k_{\text {cat }}\right)$ and the apparent $K_{\mathrm{m}}$ value for DNA can be determined. These results are shown in Table II (row 1). The apparent turnover number at $25^{\circ} \mathrm{C}$ is $15 \mu \mathrm{M}$ base pairs ${ }^{-1}(\mu \mathrm{M} \text { recBCD enzyme })^{-1}$, and the apparent $K_{\mathrm{m}}$ value is $0.6 \mathrm{nM}$ DNA molecules. The apparent $K_{\mathrm{m}}$ value for DNA and the apparent $k_{\text {cat }}$ were also calculated in the same way for helicase activity at $37^{\circ} \mathrm{C}$ (Table II, row 9). Note that the apparent $K_{\mathrm{m}}$ values are nearly the same, within error, at both 25 and $37^{\circ} \mathrm{C}$, while the apparent $k_{\text {cat }}$ at $37{ }^{\circ} \mathrm{C}$ is $56 \mu \mathrm{M}$ base pairs $\mathrm{s}^{-1}$ ( $\mu \mathrm{M}$ recBCD enzyme $)^{-1}$, a value 3.7 -fold higher than at $25^{\circ} \mathrm{C}$. Thus, the change in temperature primarily affects the rate of the unwinding reaction, rather than the binding of rec $B C D$ enzyme to its DNA substrate.

To determine the apparent $K_{\mathrm{m}}$ value for ATP in the helicase reaction, it would be necessary to maintain an amount of dsDNA at least 5 times the apparent $K_{\mathrm{m}}$ value for DNA. Since this is impractical in terms of the concentrations of DNA required, the method of Florini and Vestling (1957) was used. The ATP concentration was varied in the presence of 0.14 , 0.35 , and $0.69 \mathrm{nM}$ dsDNA molecules (the data for $0.69 \mathrm{nM}$ DNA are shown in Figure 3, circles). Double-reciprocal plots ( 1 /[DNA molecules] vs $1 /$ rate) were generated for each ATP concentration. The intercepts on the $y$ axis are not $1 / k_{\text {cat }}$ but the reciprocal of some rate dependent on substrate concentration. When these $y$-intercept values are replotted vs the reciprocal of the ATP concentration (not shown), the intercept on the $x$ axis is equal to $-1 / K_{\mathrm{m}}$ for ATP. This value is equal to $130 \pm 30 \mu \mathrm{M}$ ATP, which is well below both the in vivo concentration of ATP and the $1 \mathrm{mM}$ concentration used in the standard reaction.

It is obvious from the data in Figure 3 that an increase in ATP concentration results in an increase in the initial rate of unwinding. This supports the suggestion by Mackay and Linn (1976) that the observed nuclease activity of recBCD enzyme is inhibited at high ATP concentrations because recBCD enzyme moves more quickly through the DNA.

Effect of Enzyme Concentration on RecBCD Enzyme Helicase Activity. The concentration of recBCD enzyme was varied to determine the stoichiometry of recBCD enzyme

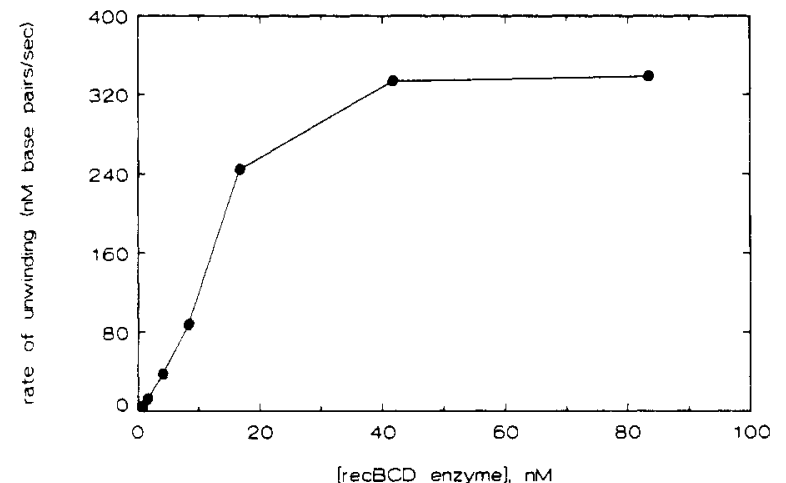

FIGURE 4: RecBCD enzyme helicase activity as a function of enzyme concentration. Assays contained $0.69 \mathrm{nM}$ dsDNA, $2.0 \mu \mathrm{M}$ SSB protein, and the indicated amount of enzyme. Standard reaction conditions were used, initial rates are plotted, and all rates are reported in units of nanomolar base pairs unwound per second.

binding. The initial rates of these reactions as a function of the recBCD enzyme concentration are shown in Figure 4. The data saturate at a rate of $325 \mathrm{nM}$ base pairs/s and a recBCD enzyme concentration of $23 \pm 3 \mathrm{nM}$, signifying that recBCD enzyme helicase activity saturates at an apparent stoichiometry of 33 recBCD molecules per DNA molecule. This same stoichiometry is also obtained when the concentration of dsDNA is reduced by half $(0.35 \mathrm{nM}$ dsDNA molecules; not shown), indicating that the stoichiometry of recBCD enzyme to dsDNA is independent of DNA concentration. This stoichiometry is consistent with that reported in the following paper for recBCD enzyme catalyzed ATP hydrolysis (Roman \& Kowalczykowski, 1989).

Assuming the simplest model for the recBCD-dsDNA complex, saturation would be expected at two recBCD molecules per DNA molecule (one monomer of $\mathrm{B}, \mathrm{C}$, and D subunits for each end of the duplex). The above data imply either that recBCD enzyme is binding nonspecifically to the internal base pairs of a DNA molecule rather than exclusively to the ends, our recBCD preparation is about $94 \%$ inactive enzyme, or that a functional recBCD enzyme is a higher multimer, as suggested by Dykstra et al. (1984).

To test whether recBCD enzyme can bind to the internal base pairs of a DNA molecule, competition experiments containing linear and supercoiled dsDNA were performed. These experiments were performed at 0,100 , and $200 \mathrm{mM}$ $\mathrm{NaCl}$ with the idea that, if nonspecific binding were occurring, it would be eliminated at higher $\mathrm{NaCl}$ concentration. $\mathrm{RecBCD}$ enzyme was preincubated with or without supercoiled M13 RF DNA ( $0.69 \mathrm{nM})$ and SSB protein. The reaction was begun with the addition of linear dsDNA $(0.35 \mathrm{nM})$. This ratio of supercoiled to linear DNA substrates represents a molar ratio of internal DNA sites to linear dsDNA ends of at least 14390 to 1 . The initial rates of unwinding are essentially unaltered by the presence of RF DNA (data not shown), indicating that the affinity of recBCD enzyme for DNA ends is at least 100-fold greater than 14390 times its affinity for internal base pairs (i.e., about $10^{6}$-fold greater).

Since recBCD enzyme does not appear to be binding nonspecifically, the high saturation point of recBCD to DNA is due either to the presence of $94 \%$ inactive enzyme in our preparation or to the requirement of a multimeric form of recBCD enzyme. The former possibility is consistent with the observation that, although the enzyme appears to be greater than $95 \%$ pure on Coomassie-stained gels, the specific activity of our preparation is approximately $11 \%$ of that of Amundsen et al. (1986), who report the highest specific activity found in the literature (fraction $\mathrm{V}, 3 \times 10^{5}$ nuclease units $/ \mathrm{mg}$ of 
protein). Our specific activity falls within the range reported by other laboratories $\left(2.1 \times 10^{4}\right.$ to $2.7 \times 10^{5}$ nuclease units $/ \mathrm{mg}$ of protein; Nobrega et al., 1972; Ponticelli et al., 1985; Taylor \& Smith, 1985; Hermanns \& Wackernagel, 1977; Dykstra et al., 1984).

To verify that this unexpected DNA binding stoichiometry was due to the presence of inactive enzyme, a subsequent preparation of recBCD enzyme, with a specific activity of 9.4 $\times 10^{4}$ nuclease units $/ \mathrm{mg}$, was also used to determine the stoichiometry of recBCD enzyme to DNA. The observed stoichiometry in this case was $6 \mathrm{nM}$ recBCD enzyme/0.69 $\mathrm{nM}$ DNA or 8.7 (not shown). Thus, the preparation of enzyme with a 3-fold higher specific activity than the preparation used for Figure 4 has a stoichiometry which is approximately one-third that of the preparation of lower specific activity. ${ }^{3}$ These data are consistent with the explanation that the anomalous stoichiometry of protein to DNA is a result of a large amount of inactive protein in all recBCD enzyme preparations, but does not exclude the possibility that the functional unit of recBCD enzyme is a multimer. In any case, the presence of inactive protein does not appear to affect helicase or ATPase activities as results obtained from all preparations (which vary from $5 \%$ to $50 \%$ active protein) were identical when equal amounts of nuclease units were used.

To extract true catalytic turnover numbers, the apparent (observed) rate needs to be corrected for the amount of active enzyme present, as defined by the stoichiometry. When the maximum observed rates of unwinding listed in Table II are corrected for the experimentally observed stoichiometry obtained from Figure 4, assuming that the true stoichiometry is one functional recBCD complex per DNA end, the rates at 25 and $37^{\circ} \mathrm{C}$ become 250 and $930 \mu \mathrm{M}$ base pairs unwound $\mathrm{s}^{-1}$ ( $\mu \mathrm{M}$ functional recBCD complex $)^{-1}$ [or (DNA end) $)^{-1}$ ], respectively. This experimentally derived correction factor is 16.5 (i.e., 33 recBCD molecules per 2 dsDNA ends) and is not dependent on specific activity determinations. This correction is necessary because the apparent, uncorrected $k_{\text {cat }}$ (bp unwound per second per $\operatorname{rec} B C D$ enzyme) is lower than the value for the number of bp unwound per second per $D N A$ end, which is a physically unrealistic situation. Correction of the apparent $k_{\text {cat }}$ in this manner results in a value which is in agreement with the rate of DNA unwinding observed per dsDNA end (Figure 4 ). The rate observed at the plateau is $325 \mathrm{nM}$ base pairs/s, and the concentration of DNA ends (i.e., the concentration of functional recBCD-dsDNA complex at saturation) is $1.38 \mathrm{nM}$; the resulting value for the turnover number is $235 \mu \mathrm{M}$ base pairs $\mathrm{s}^{-1}$ ( $\mu \mathrm{M}$ functional recBCD complex $)^{-1}$. This is equal, within experimental error, to the apparent turnover number which has been corrected for the experimentally derived stoichiometry [250 $\mu \mathrm{M}$ base pairs $\mathrm{s}^{-1}$ ( $\mu \mathrm{M}$ functional recBCD complex $\left.)^{-1}\right]$. The rates reported are those experimentally observed (apparent $k_{\text {cat }}$ ), unless specified as corrected $k_{\text {cat }}$ (bp per second per functional recBCD complex) values, which have been corrected for the observed stoichiometry.

\footnotetext{
${ }^{3}$ Also, identical rates of unwinding are obtained when equal amounts of activity based on nuclease units of (1) the preparation of recBCD enzyme used in this paper, (2) the preparation with a higher specific activity described above, or (3) preparations obtained from Andrew Taylor of the Fred Hutchinson Cancer Center [fraction IV of Taylor and Smith (1985) and fraction V of Amundsen et al. (1986); not shown] are used. Our preparation of recBCD enzyme has a specific activity which is $11 \%$ that of Amundsen et al. (1986; fraction V) and is calculated to consist of approximately $6 \%$ active enzyme. Therefore, the preparation of Amundsen et al. (1986) is 6\%/11\%, or 55\%, active. This implies either that their preparation is only half-active or that the functional recBCD helicase unit is a dimer.
}

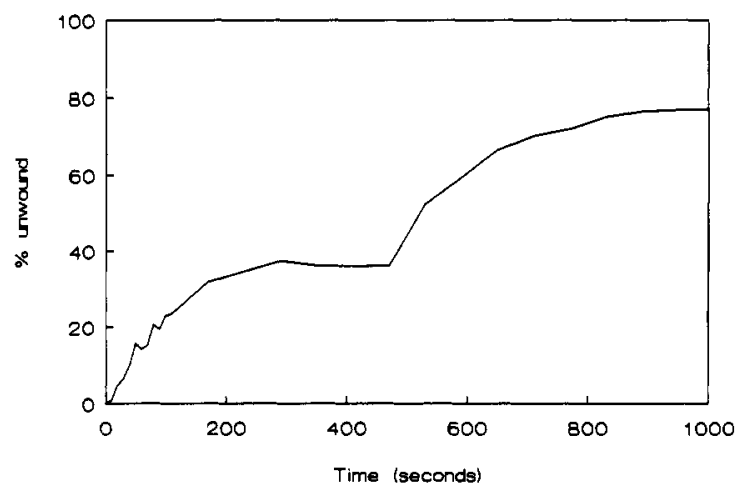

FIGURE 5: Unwinding of an additional aliquot of dsDNA by recBCD enzyme. Assay contained $0.14 \mathrm{nM}$ dsDNA molecules, $0.6 \mathrm{nM}$ recBCD enzyme, and $0.8 \mu \mathrm{M}$ SSB protein. The recBCD enzyme preparation used for these data was different from that of the other data in this paper and had a 3-fold higher specific activity. Thus, saturation of unwinding activity occurs at about 8.7 molecules of recBCD enzyme per DNA molecule for this preparation. The additional aliquot of dsDNA $(0.14 \mathrm{nM})$ was added at the plateau region of the first unwinding reaction. Standard reaction conditions were used.

A Single RecBCD Enzyme Molecule Can Unwind Multiple dsDNA Molecules. Eichler and Lehman (1977) observed that, at a concentration of ATP greater than or equal to $0.5 \mathrm{mM}$, the extent of recBCD enzyme nuclease activity is stoichiometric (i.e, directly proportional to the amount of enzyme added) rather than catalytic. They interpreted this result as an inactivation of enzyme molecules due to the formation of inhibitory enzyme-DNA product molecules. To investigate the question of reinitiation, a standard unwinding assay was performed in the presence of twice the normal amount of SSB protein. After the reaction was completed (a plateau was reached), an additional aliquot of dsDNA was added to the reaction. The second addition of dsDNA was unwound with the same initial rate [ 48.8 and $50.6 \mu \mathrm{M}$ base pairs $\mathrm{s}^{-1}(\mu \mathrm{M}$ functional recBCD enzyme complex $)^{-1}$ for the first and second reactions, respectively] and to the same extent $(75 \%$ and $81 \%$ for the first and second reactions, respectively) as the first addition of dsDNA (Figure 5). The number of recBCD enzyme molecules per total number of dsDNA molecules in this reaction is $50 \%$ of the number of recBCD molecules required for saturation. Thus, a recBCD enzyme molecule is indeed able to undergo multiple rounds of reinitiation of unwinding.

If the amount of recBCD enzyme is further reduced to $20 \%$ of the amount required for saturation, the rate of the second unwinding reaction is approximately half of the first, although all of the molecules in both DNA additions are completely unwound (not shown). The slower rate of the second unwinding is explained by the observation that recBCD enzyme helicase or ATPase activity is decreased $25-50 \%$ if incubated in reaction buffer for $10 \mathrm{~min}$ at $0.84 \mathrm{nM}$ recBCD enzyme before the addition of dsDNA. Apparently, recBCD enzyme is unstable at very low (i.e., $10^{-9} \mathrm{M}$ ) concentrations in this buffer.

Effect of Mono- and Divalent Salt Concentration on RecBCD Enzyme Helicase Activity. The initial rate of unwinding is very sensitive to the concentration of sodium chloride. As shown in Figure 6 (circles), this rate is inhibited by about $57 \%$ in the presence of $100 \mathrm{mM}$ sodium chloride and by $69 \%$ in $200 \mathrm{mM}$ salt. This effect of $\mathrm{NaCl}$ could be due to a decreased ability of recBCD enzyme to bind to its DNA substrate, which would be manifest in a change in apparent $K_{\mathrm{m}}$ values at different $\mathrm{NaCl}$ concentration, or to a direct effect on the stability of its DNA substrate molecules. To determine whether the effect of $\mathrm{NaCl}$ is on the apparent $K_{\mathrm{m}}$ or $k_{\text {cat }}$ values 


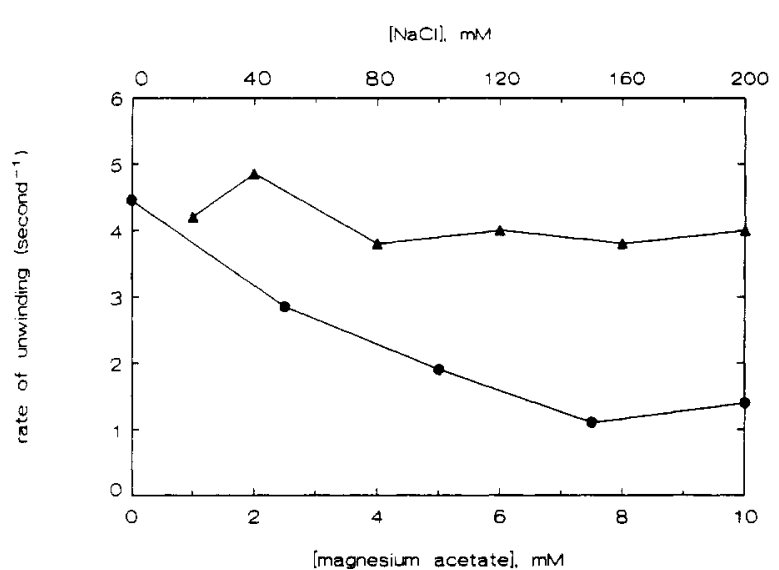

FIGURE 6: Effect of mono- and divalent ion concentration on recBCD enzyme helicase activity: sodium chloride concentration (circles); magnesium acetate concentration (triangles). Assays contained 0.14 $\mathrm{nM}$ dsDNA molecules, $0.4 \mu \mathrm{M}$ SSB protein, and $1.68 \mathrm{nM}$ recBCD enzyme. The reactions with varying magnesium acetate concentration contained no sodium chloride while the reactions with varying sodium chloride concentration contained $1 \mathrm{mM}$ magnesium acetate. Initial rates are plotted, and all rates are reported in units of micromolar base pairs unwound per second per micromolar recBCD enzyme.

or both, the dsDNA concentration was varied at $0,50,100$, 150 , and $200 \mathrm{mM} \mathrm{NaCl}$. The initial rates of unwinding for these data were fit to hyperbolas, and the apparent $k_{\text {cat }}$ and $K_{\mathrm{m}}$ values for DNA were calculated at each $\mathrm{NaCl}$ concentration. The results are shown in Table II (rows 2-5).

The apparent turnover number shows an approximately 2-fold increase to $100 \mathrm{mM} \mathrm{NaCl}$ and then declines. There is also a constant increase (2-3-fold) in the apparent $K_{\mathrm{m}}$ value with increasing $\mathrm{NaCl}$ concentration. The variation in apparent $K_{\mathrm{m}}$ value indicates that the increased salt concentration has an effect on the binding of recBCD enzyme to the ends of the dsDNA molecule.

Goldmark and Linn (1972) showed that the dsDNA nuclease activity of recBCD enzyme is strongly affected by the concentration of magnesium ion with an optimum at $10 \mathrm{mM}$ magnesium chloride. Since the magnesium ion concentration has a significant effect on nuclease activity, we were interested in whether any effect would be manifest in the helicase activity. The initial rates of unwinding as a function of magnesium acetate concentration are plotted in Figure 6. There is little or no difference in the initial rate of unwinding when the magnesium concentration is varied between 1 and $10 \mathrm{mM}$. Thus, the magnesium salt concentration has less of an effect on helicase activity than on the nuclease activity. This implies that recBCD enzyme acts at a higher rate nucleolytically at high magnesium concentrations, whereas it unwinds the DNA at the same rate as at the lower magnesium concentrations. The rate of unwinding is, however, slowed down considerably when the magnesium ion concentration is exceeded by the ATP concentration (i.e., at $1 \mathrm{mM}$ magnesium and $2.5 \mathrm{mM}$ ATP, the initial rate of unwinding is only $58 \%$ of that observed at $1 \mathrm{mM}$ magnesium and $1 \mathrm{mM}$ ATP) (data not shown).

Rosamond et al. (1979) demonstrated that, in the presence of the calcium ion, the nuclease activity of recBCD enzyme was greatly inhibited while its ATPase activity was virtually unaffected. Taylor and Smith (1980) and Telander-Muskavitch and Linn (1982) reported that recBCD enzyme will unwind dsDNA completely and with little degradation in the presence of calcium ion, but it is not known which kinetic property is affected. When standard helicase reactions (containing $0.14 \mathrm{nM}$ DNA molecules and $2.4 \mathrm{nM}$ recBCD enzyme) were performed at 1 and $5 \mathrm{mM}$ calcium acetate, we observed that the initial rate of unwinding was inhibited by
$35 \%$ and $73 \%$, respectively (not shown). The DNA substrate concentration was varied at 1 and $5 \mathrm{mM}$ calcium acetate to determine whether the inhibition observed was an effect on the apparent $k_{\text {cat }}, K_{\mathrm{m}}$, or both. These results are shown in Table II (rows 6 and 7), and it is clear that both values are affected. The apparent $K_{\mathrm{m}}$ value for DNA at $1 \mathrm{mM}$ calcium acetate does not differ from that in the absence of calcium ion, but the apparent $K_{\mathrm{m}}$ value at $5 \mathrm{mM}$ calcium acetate is 3 times higher than that observed in its absence. In the presence of either $1 \mathrm{mM}$ or $5 \mathrm{mM}$ calcium acetate, the apparent turnover number is about $70-80 \%$ of that observed in the absence of calcium ion, indicating some direct effect on the recBCD enzyme. When corrected for the experimentally observed stoichiometry, the turnover number in the presence of calcium ion is approximately $190 \mu \mathrm{M}$ base pairs $\mathrm{s}^{-1}$ ( $\mu \mathrm{M}$ functional recBCD complex $)^{-1}$. This is very similar to the rate of 200 $\mathrm{bp} / \mathrm{s}$ at $23^{\circ} \mathrm{C}$ observed by Telander-Muskavitch and Linn (1982).

Taylor and Smith (1980) observed the unwinding of dsDNA by recBCD enzyme using electron microscopy and have calculated that, at $37^{\circ} \mathrm{C}$ and with $1 \mathrm{mM}$ magnesium acetate, $1 \mathrm{mM}$ calcium acetate, and $5 \mathrm{mM}$ ATP in the buffer, recBCD enzyme will unwind dsDNA at a rate of $300 \mathrm{bp} / \mathrm{s}$. We determined the apparent turnover number and $K_{\mathrm{m}}$ value for DNA under these conditions, and they are shown in Table II (row 8). The $K_{\mathrm{m}}$ value for DNA is the same as that for 0 or $1 \mathrm{mM}$ calcium acetate at $25^{\circ} \mathrm{C}$ in the presence of $1 \mathrm{mM}$ ATP. The apparent $k_{\text {cat }}$ value is also the same as that observed at $25^{\circ} \mathrm{C}$ in the presence of calcium acetate and $1 \mathrm{mM} \mathrm{ATP}$, despite the higher temperature. This is due to the fact that the unwinding rate is decreased when the concentration of ATP exceeds the concentration of divalent ion present (see above). If corrected for the observed stoichiometry, $k_{\text {cat }}$ is $200 \pm 18$ $\mu \mathrm{M}$ base pairs $\mathrm{s}^{-1}$ ( $\mu \mathrm{M}$ functional recBCD complex $)^{-1}$, which is in reasonable agreement with the electron microscopic data.

\section{Discussion}

We have extensively characterized the DNA unwinding activity of recBCD enzyme using a novel assay for helicase activity. Detection of DNA unwinding is based on the quenching of the intrinsic protein fluorescence of SSB protein upon binding to ssDNA. A protein with helicase activity can unwind a dsDNA molecule to form ssDNA regions which are available for SSB protein binding. SSB protein binds immediately to these ssDNA regions, resulting in an easily monitored decrease in fluorescence. This assay has several advantages over the traditional assay based on the production of S1 nuclease sensitive DNA material. Our fluorometric method is continuous and does not require treating of discrete time points. It can also be used to follow a fast reaction (i.e., less than a minute) by using rapid kinetic techniques. In addition, our assay is able to measure even partially unwound molecules, unlike the $\mathrm{S} 1$ nuclease assay where a deproteination step may allow partially unwound molecules to renature. One of the disadvantages of our method is that it may not be applicable to helicases which act stoichiometrically, unless the helicase itself has a quenchable intrinsic protein fluorescence, or to helicases whose activities are altered by SSB protein.

Using this assay, we have characterized the biochemical properties of recBCD enzyme helicase activity. The apparent turnover number was determined to range from 15 up to 56 $\mu \mathrm{M}$ base pairs $\mathrm{s}^{-1}$ ( $\mu \mathrm{M}$ recBCD enzyme $)^{-1}$, depending on experimental conditions. Double-stranded DNA is unwound by recBCD enzyme to an extent which ranges from $75 \%$ to $100 \%$, under all conditions, as measured in our assay, implying that nearly all of the unwound dsDNA is trapped by the SSB 
protein. We show that recBCD enzyme cannot unwind RF DNA in our assay, a result which agrees with that of Taylor and Smith (1985), who demonstrated that the unwinding activity of recBCD enzyme required binding to the ends of dsDNA molecules. RecBCD enzyme preferentially binds dsDNA over ssDNA in the presence of SSB protein, as evidenced by its undisturbed unwinding of dsDNA when ssDNA is added either before or after the dsDNA. We demonstrate that DNA unwinding is complete with regard to recBCD enzyme activity, since the addition of recBCD enzyme after the reaction is apparently complete (i.e., at the plateau) results in no further unwinding (i.e., no fluorescence decrease). Finally, the rate of DNA unwinding is comparable to that observed with other methods (i.e., agarose gel helicase assay conducted in either the presence or absence of SSB protein and $\mathrm{S} 1$ nuclease assay) and by other investigators using electron microscopy (Taylor \& Smith, 1980; Telander-Muskavitch \& Linn, 1982), demonstrating that SSB protein instantly traps the unwound DNA without perturbing the reaction.

The extent of DNA unwinding is observed to range from $75 \%$ to $100 \%$ of the maximum amount possible. One possible reason for this observation has been discussed. ${ }^{2}$ It is probably not due to degradation of the dsDNA by recBCD enzyme to such an extent that oligonucleotides which bind poorly to SSB protein are produced. We find that no acid-soluble DNA fragments are produced under these conditions, and since SSB protein binds to oligonucleotides [oligo(dT)] as small as 16 with similar fluorescence quenching characteristics and with a dissociation constant in the nanomolar range (Molineux et al., 1975), it appears that the ssDNA fragments that may be produced are large enough to bind SSB protein. Another possibility is that less than $100 \%$ unwinding may reflect the processivity of recBCD enzyme unwinding. That is, the DNA molecules may not all be completely unwound. This partially unwound DNA would be detected in the fluorometric assay but would no longer be a substrate for subsequent recBCD enzyme action, since recBCD enzyme is unable to bind to and unwind DNA molecules with long single-stranded tails (Taylor \& Smith, 1985). This is unlikely, however, because we find that recBCD enzyme can processively unwind up to $25 \mathrm{~kb}$ of dsDNA (unpublished observation). Finally, the fluorometric assay assumes that the unwound DNA structures formed by recBCD enzyme are fully "tailed" or "loop-tailed" molecules (Taylor \& Smith, 1980; Telander-Muskavitch \& Linn, 1982). If some "twin-looped" structures are formed, then the renatured dsDNA regions would escape detection in the SSB protein binding assay. However, some dsDNA preparations yield up to $100 \%$ unwinding; ${ }^{2}$ this implies that very few twin-loop structures are forming under our conditions.

We have also demonstrated that recBCD enzyme molecules are able to catalyze multiple rounds of DNA unwinding. When additional dsDNA is added to a completed unwinding reaction containing a subsaturating concentration of recBCD enzyme, the newly introduced DNA is unwound at a rate nearly equivalent to the initial reaction rate. This result is the expected one if recBCD enzyme is truly acting as an enzyme and not being inactivated during the course of the reaction due to irreversible inhibition of the enzyme. Our result is in contrast to that of Eichler and Lehman (1977), who show that the extent of nucleolytic degradation of dsDNA by recBCD enzyme is directly proportional to the amount of enzyme added when the ATP concentration exceeds $0.5 \mathrm{mM}$. They interpreted these results as an inactivation of recBCD enzyme. Our results demonstrate that one recBCD enzyme molecule is able to reinitiate unwinding on subsequent DNA molecules until the reaction is complete.

RecBCD enzyme has an apparent maximum unwinding activity of approximately $15 \mu \mathrm{M}$ base pairs $\mathrm{s}^{-1}(\mu \mathrm{M}$ recBCD enzyme $)^{-1}$, at $25^{\circ} \mathrm{C}$ and in the absence of $\mathrm{NaCl}$ or calcium acetate. If the apparent turnover number is corrected for the experimentally observed stoichiometry of recBCD enzyme binding to dsDNA (Figure 4), then it becomes $250 \mu \mathrm{M}$ base pairs $\mathrm{s}^{-1}$ ( $\mu \mathrm{M}$ functional recBCD complex) $)^{-1}$. At $37^{\circ} \mathrm{C}$, the $K_{\mathrm{m}}$ value remains the same, and the apparent $k_{\text {cat }}$ is $56 \mu \mathrm{M}$ base pairs $\mathrm{s}^{-1}(\mu \mathrm{M} \text { recBCD enzyme })^{-1}$ or, if corrected for binding stoichiometry, $930 \mu \mathrm{M}$ base pairs $\mathrm{s}^{-1}$ ( $\mu \mathrm{M}$ functional recBCD complex $)^{-1}$.

The apparent $K_{\mathrm{m}}$ value of recBCD enzyme for dsDNA is $0.6 \pm 0.1 \mathrm{nM}$ DNA molecules or $1.2 \mathrm{nM}$ DNA ends. At higher $\mathrm{NaCl}$ concentrations, the apparent $K_{\mathrm{m}}$ value for DNA is increased approximately $2-3$-fold. The apparent $K_{\mathrm{m}}$ value for ATP in unwinding is $130 \pm 30 \mu \mathrm{M}$ ATP. These apparent $K_{\mathrm{m}}$ values are physiologically relevant when one considers the concentration of DNA ends in an $E$. coli cell. If one assumes that the volume of a cell is approximately $1.8 \mu \mathrm{m}^{3}$ (Luria, 1960), then the molar concentration of just one dsDNA end is $0.9 \mathrm{nM}$. Thus, both the apparent $K_{\mathrm{m}}$ values for DNA and ATP derived from helicase activity are similar to or below the presumptive in vivo concentrations of these substrates, indicating that the unwinding activity of $\mathrm{recBCD}$ enzyme would be significant in vivo.

To explain the observation that the ssDNA molecules produced by the nuclease activity of recBCD enzyme at ATP concentrations greater than $0.5 \mathrm{mM}$ are considerably larger than those produced at low (i.e., $20 \mu \mathrm{M}$ ) ATP concentrations, Mackay and Linn (1976) postulated that a recBCD enzyme molecule will move more quickly through a dsDNA molecule at the higher concentrations of ATP. We show that the initial rate of unwinding of a dsDNA molecule increases with increasing ATP concentration, thus supporting their notion.

A titration with recBCD enzyme at constant DNA and ATP concentrations yields a stoichiometry of 33 recBCD molecules/DNA molecule. Since recBCD enzyme can initiate unwinding only from the ends of a dsDNA molecule (Taylor \& Smith, 1985), the expected stoichiometry was 2 (although the number of recBCD molecules involved in a functional complex is unknown). Karu et al. (1973) demonstrated that RF DNA does not compete with duplex ends in an assay of recBCD enzyme ATPase activity. We have demonstrated this same result with regard to recBCD enzyme helicase activity. The presence of RF DNA has no effect on the initial rate of unwinding of linear dsDNA, implying that the affinity of recBCD enzyme for DNA ends is greater than $1.4 \times 10^{6}$ times its affinity for internal base pairs. Therefore, the high stoichiometry is not due to the nonspecific binding of recBCD enzyme to the internal base pairs of a DNA molecule but, rather, must be due either to the presence of a large amount of inactive enzyme molecules or to the requirement of a multimer of recBCD enzyme (Dykstra et al., 1984) or both. We have corrected the apparent $k_{\mathrm{cat}}$ values obtained to reflect a stoichiometry of one functional recBCD complex per dsDNA end. This yields a true catalytic turnover value per functional recBCD enzyme complex which is in agreement with electron microscopy results and with our own data when rates are expressed per dsDNA end (Figure 4).

Increasing sodium chloride concentration is inhibitory to helicase activity of recBCD enzyme. This activity is inhibited by $57 \%$ and $70 \%$ under standard conditions in the presence of 100 and $200 \mathrm{mM} \mathrm{NaCl}$, respectively. Determination of the 
apparent $K_{\mathrm{m}}$ value for dsDNA and apparent $k_{\text {cat }}$ values at increasing salt concentration shows that the observed $k_{\text {cat }}$ exhibits an optimum at $100 \mathrm{mM}$ while the apparent $K_{\mathrm{m}}$ values increase about 3-fold with increasing $\mathrm{NaCl}$ concentrations. This indicates that, in addition to an effect on the turnover number, high salt concentrations may decrease the ability of recBCD enzyme to bind to dsDNA ends. This result is consistent with the observation that most protein-nucleic acid interactions are sensitive to increases in salt concentration.

The recBCD enzyme helicase activity is absolutely dependent on the presence of the magnesium ion, as shown by the cessation of activity upon the addition of EDTA, but does not vary with increasing magnesium concentrations. This is different from both the nuclease (Goldmark \& Linn, 1975) and ATPase (Roman \& Kowalczykowski, 1989) activities of recBCD enzyme which increase with increasing magnesium concentration, with an optimum at $10 \mathrm{mM}$.

Rosamond et al. (1979) showed that calcium almost completely inhibited the nuclease activity of recBCD enzyme. In the presence of $1 \mathrm{mM} \mathrm{MgCl}_{2}$ and $1 \mathrm{mM} \mathrm{CaCl}_{2}$, nuclease activity was reduced to $2 \%$ of maximum while $99 \%$ of the ATPase activity remained. We have shown that the unwinding activity, like the nuclease activity, is inhibited by calcium ion, but to a much smaller extent. If $1 \mathrm{mM} \mathrm{MgOAc}$ and $1 \mathrm{mM}$ $\mathrm{CaOAc}_{2}$ are present, the helicase activity of recBCD enzyme is reduced to about $70-80 \%$ of the rate under the same conditions but in the absence of calcium ion. The calcium ion is probably affecting the enzyme directly, rather than just influencing its binding to DNA ends, since both the $K_{\mathrm{m}}$ and $k_{\text {cat }}$ are altered by calcium ion.

Mackay and Linn (1974) proposed a model for the action of recBCD enzyme which predicted that the enzyme would use energy derived from ATP hydrolysis to unwind dsDNA. This is substantiated by the following paper (Roman \& Kowalczykowski, 1989) where the ATPase and helicase activities of recBCD enzyme are shown to be closely related under most conditions (although they can be uncoupled) and that the number of ATP molecules hydrolyzed per base pair unwound is approximately $2-3$. Since, however, the helicase activity of the enzyme is decreased by calcium ion while the ATPase activity is apparently unaffected (Rosamond et al., 1979), it appears that calcium ions will make the enzyme less efficient (i.e., a greater number of ATP molecules are hydrolyzed for every base pair unwound). Similarly, an increase in magnesium ion concentration will cause this effect. Since the initial rate of ATPase activity increases with an increase in magnesium ion concentration [see Roman and Kowalczykowski (1989)] while the helicase activity of recBCD enzyme remains virtually unchanged, a larger number of ATP molecules are hydrolyzed for every base pair unwound. Thus, although these divalent ions appear to exert a greater effect on the nuclease activity of recBCD enzyme than on its helicase activity, they do affect the efficiency of ATP hydrolysis during the unwinding of dsDNA. This efficiency is discussed in more detail in the following paper (Roman \& Kowalczykowski, 1989).

Finally, we wish to propose a new unit of enzymatic activity for recBCD enzyme based on helicase activity. A unit based on the helicase activity of recBCD enzyme would be more relevant to the study of this activity than a unit based on dsDNA exonuclease activity. In addition, since exonuclease activity is very sensitive to ionic conditions (e.g., magnesium and calcium ion concentration) whereas helicase activity is not, activity defined by helicase activity would be subject to less inconsistency. Therefore, we suggest that 1 unit of recBCD enzyme unwinding activity is equal to the amount required to unwind $1 \mathrm{nmol}$ of base pairs in $1 \mathrm{~min}$ at $25^{\circ} \mathrm{C}$, in standard buffer containing $1 \mathrm{mM}$ magnesium acetate, $1 \mathrm{mM} \mathrm{ATP}$, and $0.6 \mathrm{nM}$ dsDNA molecules. Since the apparent $K_{\mathrm{m}}$ value of recBCD enzyme for dsDNA molecules is equal to $0.6 \pm 0.1$ $\mathrm{nM}$, the measured rate would be equal to half of the apparent $k_{\text {cat }}$. For comparison, our preparation of recBCD enzyme has $7.7 \times 10^{3}$ helicase units $/ \mathrm{mg}$ and $3.4 \times 10^{4}$ nuclease units $/ \mathrm{mg}$. Therefore, in our preparation, 1 helicase unit is equal to 4.4 nuclease units. Finally, on the basis of the data presented in the following paper (Roman \& Kowalczykowski, 1989), the helicase activity of recBCD enzyme could be readily determined from the ATPase activity and vice versa. The ATPase activity of recBCD enzyme has the advantage of being perhaps the easiest assay of enzyme activity to measure.

\section{ACKNOWLEDGMENTS}

We are grateful to Andrew Taylor, Dennis Schultz, and Gerald Smith of the Fred Hutchinson Cancer Center in Seattle for the gifts of $E$. coli strains and of recBCD enzyme with which preliminary experiments were performed. We are also grateful to Polly E. Lavery and Joseph P. Menetski for critical reading of the manuscript.

Registry No. ATP, 56-65-5; calcium, 7440-70-2.

\section{REFERENCES}

Amundsen, S. K., Taylor, A. F., Chaudhury, A. M., \& Smith, G. R. (1986) Proc. Natl. Acad. Sci. U.S.A. 83, 5558-5562. Birge, E. A., \& Low, K. B. (1974) J. Mol. Biol. 83, 447-457. Bujalowski, W., \& Lohman, T. M. (1986) Biochemistry 25, 7799-7802.

Chaudhury, A. M., \& Smith, G. R. (1984) Proc. Natl. Acad. Sci. U.S.A. 81, 7850-7854.

Dykstra, C. C., Palas, K. M., \& Kushner, S. R. (1984) Cold Spring Harbor Symp. Quant. Biol. 49, 463-467.

Eichler, D. C., \& Lehman, I. R. (1977) J. Biol. Chem. 252, 499-503.

Finch, P. W., Wilson, R. E., Brown, K., Hickson, I. D., Tomkinson, A. E., \& Emmerson, P. T. (1986a) Nucleic Acids Res. 11, 4437-4451.

Finch, P. W., Storey, A., Chapman, K. E., Brown, K., Hickson, I. D., \& Emmerson, P. T. (1986b) Nucleic Acids. Res. 21, 8573-8582.

Finch, P. W., Storey, A., Brown, K., Hickson, I. D., \& Emmerson, P. T. (1986c) Nucleic Acids Res. 21, 8583-8594.

Florini, J. R., \& Vestling, C. S. (1957) Biochim. Biophys. Acta $25,575$.

Goldmark, P. J., \& Linn, S. (1972) J. Biol. Chem. 247, 1849-1860.

Hermanns, U., \& Wackernagel, W. (1977) Eur. J. Biochem. $76,425-432$.

Karu, A. E., MacKay, V., Goldmark, P. J., \& Linn, S. (1973) J. Biol. Chem. 248, 4874-4884.

Lieberman, H. B., \& Oishi, M. (1974) Proc. Natl. Acad. Sci. U.S.A. $71,4816-4820$.

Luria, S. E. (1960) The Bacteria, Vol. 1, pp 1-34, Academic Press, New York.

MacKay, V., \& Linn, S. (1974) J. Biol. Chem. 249, 4286-4294.

Mackay, V., \& Linn, S. (1976) J. Biol. Chem. 251, 3716-3719.

Messing, J. (1983) Methods Enzymol. 100, 20-78.

Molineux, I. J., Pauli, A., \& Gefter, M. L. (1975) Nucleic Acids Res. 10, 1821-1837.

Nobrega, F. G., Rola, F. H., Padetto-Nobrega, M., \& Oishi, M. (1972) Proc. Natl. Acad. Sci. U.S.A. 69, 15-19. 
Ponticelli, A. S., Schultz, D. W., Taylor, A. F., \& Smith, G. R. (1985) Cell (Cambridge, Mass.) 41, 145-151.

Porter, R. D., McLaughlin, T., \& Low, B. (1978) Cold Spring Harbor Symp. Quant. Biol. 43, 1043-1047.

Roman, L. J., \& Kowalczykowski, S. C. (1989) Biochemistry (following paper in this issue).

Rosamond, J., Telander, K. M., \& Linn, S. (1979) J. Biol. Chem. 254, 8646-8652.

Smith, G. R. (1987) Annu. Rev. Genet. 21, 179-201.

Smith, G. R., Amundsen, S. K., Chaudhury, A. M., Cheng, K. C., Ponticelli, A. S., Roberts, C. M., Schultz, D. W., \& Taylor, A. F. (1984) Cold Spring Harbor Symp. Quant. Biol. 49, 485-495.

Stahl, F. W. (1986) Prog. Nucleic Acid Res. Mol. Biol. 33, 169-194.
Taylor, A. F. (1988) Genetic Recombination (Kucherlapati, R., \& Smith, G. R., Eds.) pp 231-263, American Society for Microbiology, Washington, DC.

Taylor, A. F., \& Smith, G. R. (1980) Cell (Cambridge, Mass.) $22,447-457$.

Taylor, A. F., \& Smith, G. R. (1985) J. Mol. Biol. 185, 431-443.

Taylor, A. F., Schultz, D. W., Ponticelli, A. S., \& Smith, G. R. (1985) Cell (Cambridge, Mass.) 41, 153-163.

Telander-Muskavitch, K., \& Linn, S. (1981) The Enzymes (Boyer, P. D., Ed.) pp 233-250, Academic Press, New York.

Telander-Muskavitch, K., \& Linn, S. (1982) J. Biol. Chem. 257, 2641-2648.

Yancey, S. D., \& Porter, R. D. (1985) J. Bacteriol. 162, 29-34.

\title{
Characterization of the Adenosinetriphosphatase Activity of the Escherichia coli RecBCD Enzyme: Relationship of ATP Hydrolysis to the Unwinding of Duplex $\mathrm{DNA}^{\dagger}$
}

\author{
Linda J. Roman and Stephen C. Kowalczykowski* \\ Department of Molecular Biology, Northwestern University Medical School, Chicago, Illinois 60611 \\ Received September 30, 1988; Revised Manuscript Received December 7, 1988
}

\begin{abstract}
We find that the rate of dsDNA-dependent ATPase activity is biphasic, with a fast component which represents the unwinding of the dsDNA and a slow component which results from the ssDNA-dependent ATPase activity of recBCD enzyme. Comparison of the ATPase and helicase activities permits evaluation of the efficiency of ATP hydrolysis during unwinding. This efficiency can be calculated from the maximum rates of ATPase and helicase activities and is found to range between 2.0 and 3.0 ATP molecules hydrolyzed per base pair of DNA unwound. The number of ATP molecules hydrolyzed per base pair unwound is not altered by temperature but does increase at low concentrations of DNA and high concentrations of sodium chloride and magnesium acetate. The apparent $K_{\mathrm{m}}$ values for the DNA and ATP substrates of recBCD enzyme dsDNA-dependent ATPase activity at $25^{\circ} \mathrm{C}$ were determined to be $0.13 \mathrm{nM}$ DNA molecules and $85 \mu \mathrm{M}$ ATP, respectively. The observed $k_{\text {cat }}$ value is approximately $45 \mu \mathrm{M} \mathrm{ATP} \mathrm{s}^{-1}(\mu \mathrm{M}$ recBCD enzyme $)^{-1}$. If this rate is corrected for the measured stoichiometry of recBCD enzyme binding to dsDNA, the $k_{\text {cat }}$ for ATPase activity corresponds to an ATP hydrolysis rate of approximately 740 ATP molecules $\mathrm{s}^{-1}$ (functional recBCD complex) ${ }^{-1}$ at $25^{\circ} \mathrm{C}$.
\end{abstract}

Th he recBCD enzyme is composed of three nonindentical subunits which together catalyze five distinct biochemical reactions: single-stranded DNA (ssDNA) ${ }^{1}$ exo- and endonuclease activities, dsDNA exonuclease activity, helicase activity, and a DNA-dependent ATPase activity [for reviews, see Telander-Muskavitch and Linn (1981) and Taylor (1988)]. We have extensively characterized the helicase activity of recBCD enzyme (Roman \& Kowalczykowski, 1989) and now wish to examine the DNA-dependent ATPase activity and its relationship to the unwinding of dsDNA.

Characterization of the ATPase activity of recBCD enzyme has, to date, been performed under conditions such that it could be studied as a component of recBCD enzyme nuclease activities. Eichler and Lehman (1977) and Goldmark and Linn (1972) showed that the degradation of dsDNA by recBCD

\footnotetext{
${ }^{\dagger}$ This work was supported in part by funds from National Institutes of Health Grant AI-18987 and by American Cancer Society Junior Faculty Fellowship JFRA-70.

*Address correspondence to this author.
}

enzyme requires ATP and exhibits an optimum at $20 \mu \mathrm{M}$ ATP. Under these conditions, the products of the nuclease reaction are single-stranded oligonucleotides three to eight bases long. They have also demonstrated that the extent of exonuclease activity is inhibited at high $(>200 \mu \mathrm{M})$ concentrations of ATP where the product lengths range from 135 to 1400 nucleotides (Mackay \& Linn, 1976) while the initial rate of nuclease activity remains unaffected. This difference in products at low and high ATP concentrations led Mackay and Linn (1976) to propose the explanation that recBCD enzyme nicks the DNA at a constant rate but moves more quickly through the dsDNA at higher ATP concentration, thus releasing larger product molecules. We have shown (Roman \& Kowalczykowski, 1989) that recBCD enzyme does, indeed,

\footnotetext{
${ }^{1}$ Abbreviations: ssDNA, single-stranded DNA; dsDNA, doublestranded DNA; SSB protein, $E$. coli ssDNA binding protein; RF, replicative form; SDS, sodium dodecyl sulfate; DTT, diithiothreitol; ATP, adenosine triphosphate; EDTA, ethylenediaminetetraacetic acid; NADH, nicotinamide adenine dinucleotide (reduced).
} 